were on display during the seminar in the Mathematics Department. Special facilities for consulting relevant Iiterature were offered by the staff of the Rutherford Library, who also prepared an exhibit of old books, pictures and other items of historical and mathematical interest.

Thanks are due to a number of wives of Alberta staff members who entertained the visiting ladies. Informal hospitality was extended also by several members of the Mathematics and Physics staffs to various groups of visitors.

\title{
CANADIAN MATHEMATICAL CONGRESS, BANFF
}

$$
\text { Septemier } 1 \text { - September 7, } 1957
$$

Immediately following the seminar in Edmonton the fourth quadrennial Mathematical Congress was held in Banff, Alberta. The Canadian Association of Physicists (Theoretical Physics Division) participated in this, as they did in the seminar.

About 250 persons, including wives and children, attended the Congress. The majority were housed in the chalets of the Banff School of Fine Arts, but a considerable overflow had to be accommodated in the Y.M.C.A. and in other bulldings at a little distance from the School. Local arrangements were capably looked after by Dr. D.R. Crosby.

All meetings were held in the Administration Bullding at the School. The program included a panel discussion on High School mathematics (Prof. S. Jennings presiding). At the latter an excellent talk was given by Mr. P.L. Kartzke, a Vice-President of the Shell Oil Company, on the type of university training that an oil company would like to see given to those men it recruits. He emphasized the importance of fundamental science and general education, rather than industrial techniques.

Invited addresses were given as follows:

D.H. Lehmer, Jean McDonald, H.S.M. Coxeter,
"Some aspects of modern computing" "A problem in astrophysics, programmed for Ferut (the Toronto machine)" "The symmetry groups of the regular 
polytopes in unitary n-space" (two lectures)

A.D. Alexandrov,

"Uniqueness theorems for surfaces

J. Dixmier,

A. Erdély1

E.P. Wigner,

P. HaIl

E.N. Adams,

J. Bardeen,

J. Schwinger,

P. Morrison, in the large"

Quelques problèmes actuels concernant l'enseignement math. en France

"The principle of stationary phase"

"The distribution of characteristic values of matrices"

"The algebra of partitions"

"Energy bonds induced by large magnetic fields"

"Superconductivity" (two lectures)

"Theory of flelds"

"On the evidence for universal gravitation".

Sessions were held for contributed papers in (1) geometry and analysis (2) algebra (3) solid state physics (5) parity and related topics (6) field theory.

The social side of the Congress was by no means neglected. The participants in the Edmonton seminar (with the exception of a few to whom the attractions of Jasper Park and the Columbia Icefleld proved Irresistible) journeyed to Banff by way of Calgary, on Saturday, August 31st, and at Calgary they were tendered a civic dinner by the Mayor in the dining-room of the new Jubliee Auditorium. Prof. R.L. Jeffery, the president-elect of the Congress, gave the principal address.

At Banff the next day there was a reception in the auditorium of the Banff School at which Senator D. Cameron extended greetings .

On Monday, September 2nd, delegates (and wives and children) had tea at Mt. Norquay Ski Lodge, where most of them tried out the chair lift and enjoyed the wonderful view. Wednesday was given over to a scenic trip to Lake Louise and Moraine Lake, from which some of the more energetic visitors made the climb up to the top of Sentinel pass. Fortunately the weather was fine, and a box lunch eaten at Moraine lake was thoroughiy enjoyed.

In the evening a dinner tendered by the Government of Alberta was held in the Dining Room of the Banff School, preceded by a sherry party given by Professor and Mrs. G. de B. Robinson. After dinner the guests adjourned to the auditorium, where short addresses of welcome were given by the Hon. A.R. Patrick (Minister 
of Economic Affalrs for Alberta), Mr. B.I.M. Strong (Superintendent of the Banff Park), and Dr.A. Stewart (President of the University). Prof. Robinson delivered his Presidential Address to the Congress. A very enjoyable concert, given by students trained at the Banff School, concluded the evening. The artists (volce, piano and violin) were introduced by Senator Cameron.

On Friday evening, September 6 th, the Theoretical Physicists gave a party in the Solarium.

The concluding business meeting of the Congress was held on Saturday morning, and by the evening most members had departed for their various destinations.

\section{NEWS FROM THE DEPARTMENTS}

University of Alberta: Dr. I.N. Baker, a graduate of the University of Adelaide, has been appointed Assistant Professor. His thesis on entire functions has been accepted at the University of Tubingen (Germany) for the degree of Dr. rer. nat. Dr. G.C. Cree, a graduate of McGill and Washington University (St. Louis), has joined the staff as Assistant Prolessor. He was formerly at the University of Nebraska, in Lincoln. Dr. Shanti S. Gupta, a graduate in mathematical statistics of the University of North Carolina, and latterly employed with the Bell Telephone Laboratories at Allentown, $\mathrm{Pa}$, has been appointed Associate Professor. Dr. H.F.J. Lowig of the University of Tasmania (Hobart) and formerly from Czechoslovakia, has been appointed Associate Professor; his special fleld is algebra. Mr. W. Zayachkowsk1 and Mr. H.M.W. Edgar have been appointed part-time teaching assistants for this year. Mr. A. Cseuz recelved the degree of M. Sc. at the November convocation for a thesis on "An Optimal Property of the Polncare Model of Hyperbolic Geometry", under the direction of Dr. H. Helfenstein.

Prof. J.G. Kemeny w1ll be spending four days here in March as a Mathematical Association of America Visiting Lecturer. Prof. P. Erdos will be with us for the whole of April as a Visiting Professor. Dr. I. Guttman and Dr. H. Helfenstein are on leave of absence for 1957-58; Dr. Helfenstein 1s Visiting Assistant Professor at the University of Ottawa.

The University of Alberta has acquired its own electronic digital computer, an L.G.P. 30. The machine is installed in the Physics Department and is being 